エディトリアル

\title{
「脳死と Neurosonology」について
}

\section{塩貝敏之}

京都武田病院脳神経科学診療科

\section{Editorial}

\section{"Brain Death and Neurosonology"}

\section{Toshiyuki SHIOGAI}

Department of Clinical Neurosciences, Kyoto Takeda Hospital

現在における脳死の超音波診断は, Doppler 血流速度の 絶対值ではなく，その血流速波形の变化に基づいて定性的 になされている ${ }^{3,5,11)}$. 脳機能と密接に関連する脳血管床 における血流の変化は, 脳灌流圧 $(\mathrm{CPP})$, 血流抵抗と血 流量の 3 つの因子よりなる Poiseulle の法則が適応される 圧-流量関係の概念により説明されている。この血流速波 形の pulsatility の上昇のメカニズムは複雑で, 脳血管の vascular tone や脳血管抵抗に関連する細動脈の収縮のみ が関与するのではなく，心拍数や全身の末梢血管抵抗や心 拍出量などの全身の心血管因子にも強く影響されることも 知られている ${ }^{1)}$. 一方, 脳死に至る病態生理において, 頭 蓋内圧（ICP）方進に伴う CPP の低下による頭蓋内の圧 環境の変化と, 脳血管のコンプライアンスの変化は Windkessel 効果とも関連し, brain tamponade におけ る重要な因子とされる ${ }^{6)}$.

本特集においては, 脳死に至る機序のうち最も重要な病 態である ICP 元進に伴う CPP 低下と Doppler 血流速波形 の変化に関して, 実験的な解析を ICP の観点から ${ }^{4)}$ と, 脳血流之脳機能との関連から ${ }^{7)}$, 解説していただいた。両 グループ共に Doppler と ICP に関する研究を, 古くから 手がけてこられたからである ${ }^{8,10)}$. さらに臨床的な観点か ら脳死と Neurosonology に関する review を行い, 現在 における脳死判定における超音波診断の現状をまとめた ${ }^{9}$.

臨床における脳死の発生機序は, 前述の ICP 元進・CP $\mathrm{P}$ 低下のみならず多種多様な因子が関連するため, 脳血流 之脳機能の関係はより複雑で, 全脳の血流停止と不可逆的 な全脳の機能消失の閾值はその程度と時間とも関連して簡 単に決定できるものではない，さらに，脳死自体の脳血流 動態が常に完全な頭蓋内の血流停止ではないという事実か ら，画一的な所見が得られないのあ判定基準に採用されが たい一因である。しかしながら，脳死に至る重症脳障害患 者における Doppler を用いた研究は重要であり, 最近で あ精力的に行われ頭蓋内の圧一流量関係における新しい知 見む得られている ${ }^{2)}$. 何れにしてもこの分野が，今後む Neurosonology において, 魅力的かつ重要であることは 言うまであないことであろう.

\section{文献}

1) Aaslid R: Cerebral dynamics. in Newell DW, Aaslid R (eds): Transcranial Doppler. New York: Raven press, Ltd. 1992, pp49-55

2) Czosnyka M, Smielewski P, Piechnik S, Al-Rawi PG, Kirkpatrick PJ, Matta BF, Pickard JD: Critical closing pressure in cerebrovascular circulation. J Neurol Neurosurg Psychiatry 66: 606-611, 1999

3) Ducrocq $X$, Hassler W, Moritake K, Newell DW, von Reutern G-M, Shiogai T, Smith RR (Task Force Group on cerebral death of the Neurosonolgy Research Group of the World Federation of Neurology): Consensus opinion on diagnosis of cerebral circulatory arrest using Dopplersonography. J Neurol Sci 159: 145-150, 1998

4）原 圭太, 中谷 進, 尾崎孝次, 吉峰俊樹 : 頭蓋内圧之 TCD による頭蓋内血流動態の検討. Neurosonology 13: 5559,2000

5) Hassler W, Steinmetz H, Pirschel J: Transcranial Doppler study of intracranial circulatory arrest. J Neurosurg 71: 195 $-201,1989$

6) Lindegaard K-L, Grip A, Nornes H: Precerebral haemodynamics in brain tamponade. Part 2: Experimental studies. Neurochirurgia 23:187-198, 1980

7）永井秀政, 森竹浩三 : 脳血流・脳機能低下とドプラ血流速 波形変化に関する実験的検討一頭蓋内圧元進モデルと脳死一. Neurosonology 13: 60-64, 2000

8) Nakatani S, Ozaki K, Hara K, Mogami H: Intracranial volume and pressure load tolerance evaluated by continuous measurement of Doppler flow velocity on intracranial vessel in cats. in Hoff JT, Betz AL (eds): Intracranial Pressure VII, Berlin, Heidelberg: Springer-Verlag, 1989, pp109-112

9）塩貝敏之 : 脳死亡 Neurosonology. Neurosonology 13: 6570,2000

10) Takaya M, Moritake $K$, Fukuma A, Kagawa T, Nagai H: An experimental study on the transcranial Doppler ultrasonography in raised intracranial pressure. in Oka M, von Reutern G-M, Furuhata H, Kodaira K (eds): Recent Advances in Neurosonology. Tokyo: Elsevier Science Publishers BV, 1992, pp233-237

11) Yoneda $S$, Nishimoto $A$, Nukada $T$, Kuriyama $Y$, Katsurada K, Abe H: To-and-fro movement and external escape of carotid arterial blood in brain death cases. A Doppler ultrasonic study. Stroke 5: 707-713, 1974 